\title{
Rooting cuttings of Ilex paraguariensis native to southern Brazil according to mother tree genotype, rooting environment and IBA use
}

\author{
Estaquia de llex paraguariensis nativa do Sul do Brasil de acordo com o \\ genótipo da planta matriz, ambiente de enraizamento e uso de AlB \\ Bruno Nascimento ${ }^{1}$ (D), Alexandra Cristina Schatz Sá1 (1), Carolina Moraes ${ }^{1}$ (D), Julio Cesar Pires Santos ${ }^{1}$ (1), \\ Mariane de Oliveira Pereira' ${ }^{1}$, Marcio Carlos Navroski ${ }^{1}$ (B) \\ ${ }^{1}$ Universidade do Estado de Santa Catarina - UDESC, Lages, SC, Brasil
}

How to cite: Nascimento, B., Sá, A. C. S., Moraes, C., Santos, J. C. P., Pereira, M. O., \& Navroski, M. C. (2020). Rooting cuttings of Ilex paraguariensis native to southern Brazil according to mother tree genotype, rooting environment and IBA use. Scientia Forestalis, 48(128), e3087. https://doi.org/10.18671/scifor.v48n128.24

\begin{abstract}
Vegetative propagation is an effective tool for the establishment of plants with superior characteristics. Therefore, it is necessary to test the rooting of each genotype in relation to the environment and observe the response of the species to the use of growth regulators. The objective of this search was to evaluate the rooting of Ilex paraguariensis cuttings according to genotypes in two environments, and test doses of IBA. The cuttings were obtained in Urupema, Santa Catarina. Mother trees 15 years old on average, were selected randomly, and canopy shoots were collected and transported to UDESC, in Lages. The shoots were sectioned into cuttings and put to root according to the experiments: I) Six genotypes were conditioned in two environments: a mini tunnel system and a greenhouse with intermittent nebulization (GWIN) with temperature control, II) In a mini tunnel with IBA concentrations: $\left(\mathrm{mg} \mathrm{L}^{-1}\right): 0,2,500,5,000$, 7,500 and 10,000 . Survival (\%), callus (\%), rooting (\%), number and mean root length $(\mathrm{cm})$ were evaluated. Survival was superior in mini tunnels $(>20.0 \%)$, but its rooting percentages were lower $(35.0 \%)$ than the GWIN (>50.0\%). Genotype G6 was higher in all variables, with survival $(>70.0 \%)$ and rooting $(>30.0 \%)$. The highest IBA dose reached twice as much rooting as the control, but it was still low (15.0\%). The correct selection of the genotype and environment are crucial for the successful rooting of $I$. paraguariensis cuttings. In addition, rooting seems to be more associated to the time factor than to the use of IBA itself.
\end{abstract}

Keywords: Cuttings; Growth regulator; Mate tree; Micro sprinkler; Nebulization.

\section{Resumo}

A propagação vegetativa é uma ferramenta efetiva no estabelecimento de plantas com características superiores. Para tanto, é necessário testar o enraizamento de genótipos em relação ao ambiente e observar a resposta da espécie ao uso de reguladores de crescimento. O objetivo deste trabalho foi avaliar o enraizamento de genótipos de llex paraguariensis em dois ambientes e testar doses de AIB. Os propágulos foram obtidos em Urupema, Santa Catarina. Com média de 15 anos de idade, as árvores matrizes foram selecionadas aleatoriamente, tendo as brotações de suas copas coletadas e transportadas para a UDESC, em Lages. As brotações foram seccionadas em estacas e postas para enraizar de acordo com os experimentos: I) Seis genótipos acondicionados em dois ambientes, sendo um estufim e outro uma casa de vegetação com nebulização intermitente e controle de temperatura, II) Em estufim sob as doses de AIB: $\left(\mathrm{mg} \mathrm{L}^{-1}\right): 0,2.500,5.000,7.500$ e 10.000. Foram avaliados: sobrevivência (\%), calos (\%), enraizamento (\%), número e comprimento médio $(\mathrm{cm})$ de raízes. Sobrevivência foi maior

Financial support: FAPESC - grupo de pesquisa Gestão de Recursos Florestais (PAP2019031000055), Coordenação de Aperfeiçoamento de Pessoal de Nível Superior (CAPES) código 001.

Conflict of interest: Nothing to declare.

Corresponding author: b.nascimento_92@hotmail.com

Received: 20 September 2018.

Accepted: 26 November 2019.

Editor: Paulo Henrique Müller Silva.

(i) This is an Open Access article distributed under the terms of the Creative Commons Attribution License, which permits unrestricted use, cc) distribution, and reproduction in any medium, provided the original work is properly cited. 
em estufim (>20,0\%), mas o enraizamento foi menor $(35,0 \%)$ que na casa de vegetação $(>50,0 \%)$. 0 genótipo G6 foi superior em todas as variáveis, principalmente quanto sobrevivência $(>70,0 \%)$ e enraizamento (>30,0\%). A maior dose de AIB atingiu o dobro de enraizamento da não aplicação, mas ainda considerado baixo (15,0\%). A seleção correta do genótipo e ambiente são cruciais no sucesso do enraizamento de estacas de I. paraguariensis. Ainda, o enraizamento aparenta estar mais associado ao fator tempo do que o uso de AIB.

Palavras-chave: Estaquia; Regulador de crescimento; Erva-mate; Microaspersão; Nebulização.

\section{INTRODUCTION}

The use of the sexual route in breeding is important because it ensures greater genetic diversity and provides that certain desirable characteristics of the mother tree are inherited (Xavier et al., 2013). However, in addition to not having a standardization of the seedlings, there may be a low number of seeds produced and associated with the possibility of dormancy, long periods of germination and high genetic heterogeneity are caused by sexual reproduction (Xavier et al., 2013; Wendling \& Brondani, 2015).

Vegetative propagation can solve some of these problems by using genetically superior mother trees, with cuttings being one of the most used techniques for this purpose (Wendling \& Brondani, 2015). Certain advantages of this technique are: direct transmission of desirable characteristics, homogenization of the plants produced and possibility of continuous production throughout the year (Dias et al., 2012). The main factor that guarantees the success of this technique lies in the adventitious rooting of the cuttings produced (Hartmann et al., 2011). Therefore, some characteristics should be taken into account: the genotype used (Wendling \& Dutra, 2010), the rooting environment (Pires et al., 2013) and the use of growth regulators (Hartmann et al., 2011).

One of the most important factors for success in rooting is genetics when different genotypes of the same species respond differently to cutting rooting (Franzon et al., 2010). Environments with nebulization irrigation favour the survival of cuttings and their rooting, mainly by keeping the leaves functional for longer (Wendling \& Brondani, 2015). An environment with high and constant humidity is essential for maintaining the survival of cuttings (Xavier et al., 2013). The use of growth regulators in cuttings, such as IBA, increase auxin levels in the basal cuttings, helping in the root formation by cell differentiation (Hartmann et al., 2011).

Ilex paraguariensis Saint Hilaire, Aquifoliaceae family, also known as mate, is a characteristic species with a strong cultural link in Southern Brazil, and has a wide potential of use, from consumption in the less industrialized form, such as teas, to the pharmaceutical and cosmetic industry (Dartora et al., 2013). Like other crops, I. paraguariensis plantations should be constituted by superior plants, selecting seedlings of productive characteristics of interest. Although it is the best technique for selection in genetic improvement, the vegetative propagation of this species does not yet have efficient protocols for the rooting of cuttings, with capacity of application on a large commercial scale (Wendling \& Brondani, 2015).

There are still few studies on I. paraguariensis improvement through the use of vegetative propagation and selection of superior mother trees (Wendling \& Brondani, 2015). Both the survival of cuttings and their rooting are dependent on their genetic characteristics (Brondani et al., 2008). In searches done, there was no evidence of differences in rooting of cuttings between environments with a greater control of variables, such as temperature and irrigation, in relation to environments with lower control (Brondani et al., 2008, 2009). Currently, there are no precise recommendations for IBA dosage on cuttings of this species, and high concentrations (above 5,000 $\mathrm{mg} \mathrm{L}^{-1}$ ) are always recommended (Wendling \& Brondani, 2015).

Therefore, the objective of this study was to observe the development of six genotypes of $I$. paraguariensis concerning the rooting of cuttings under two distinct environments: one with greater temperature and humidity control, and another simpler and of lower cost, also to evaluate the influence of different concentrations of IBA on the rooting of cuttings of this species, related to the time factor. 


\section{MATERIAL AND METHODS}

\section{Characteristics of the area of study}

The field experiment was conducted in an experimental area in the municipality of Urupema, in Santa Catarina. The study area is located approximately 1,400 meters above sea level, at the coordinates are $28^{\circ} 17^{\prime} 38^{\prime \prime} \mathrm{S}, 49^{\circ} 55^{\prime} 54^{\prime \prime} \mathrm{W}$.

This region has a humid temperate climate $(\mathrm{Cfb})$, with annual mean precipitation of $1.650 \mathrm{~mm}$. It is characteristic of the region that during winter there can be snow and minimum temperatures of up to $-14{ }^{\circ} \mathrm{C}$, considered to be the coldest in Brazil.

\section{Cutting of different genotypes of $\boldsymbol{I}$. paraguariensis in two rooting environments}

In August 2017 six I. paraguariensis mother trees at least $20 \mathrm{~m}$ apart from each other, with an average diameter of $8.0 \mathrm{~cm}$, were selected for collecting shoots from the canopy.

The shoots were collected, arranged in a Styrofoam box with water to avoid moisture loss and transported to the Forest Nursery of the State University of Santa Catarina (UDESC), in the municipality of Lages. There shoots were sectioned into cuttings of approximately $7 \mathrm{~cm}$ in length and having at least one leaf with $50 \%$ of its area removed.

The cuttings were put to root in tubes of $110 \mathrm{~cm}^{3}$ with a mix of commercial substrate (mixture of Pinus bark and peat, $\mathrm{pH}$ 5.4) and thin vermiculite in the ratio 1:1, with the addition of $6 \mathrm{~g} \mathrm{~L}^{-1}$ slow release fertilizer (Osmocote ${ }^{\circledR}$ 15-9-12).

The experiment was conducted in a completely randomized design with $6 \times 2$ factorial arrangement, with factor $A$ consisting of the six genotypes, composed of eight replicates of six cuttings each, and $B$ the 2 rooting environments.

The trays containing the tubes and cuttings were conditioned in two different rooting environments (factor B), as:

I- In a mini tunnel, a simplified structure, inserted in a shade house, located in the Forest Nursery of UDESC, in Lages, Santa Catarina state, with automatic irrigation by micro sprinklers composed with four daily irrigations of five minutes each. According to the classification of Köppen, the region has a warm and temperate climate ( $\mathrm{Cfb}$ ), with average temperature of $16.6^{\circ} \mathrm{C}$ and average annual precipitation of $1,441 \mathrm{~mm}$.

II- In a greenhouse with intermittent nebulization (GWIN) of a forest company, in the municipality of Otacílio Costa, Santa Catarina state, with automatic temperature control (between $20^{\circ} \mathrm{C}$ and $30^{\circ} \mathrm{C}$ ) by thermostat and humidity (always above $80.0 \%$ ). Similar to the climate of Lages, Otacílio Costa has a warm and temperate climate $(\mathrm{Cfb})$ according to the Köppen classification, with an average temperature of $16.3^{\circ} \mathrm{C}$ and average precipitation of $1,519 \mathrm{~mm}$.

The temperature and humidity data from both sites were obtained from a data logger, giving a reading every ten minutes (Figure 1).

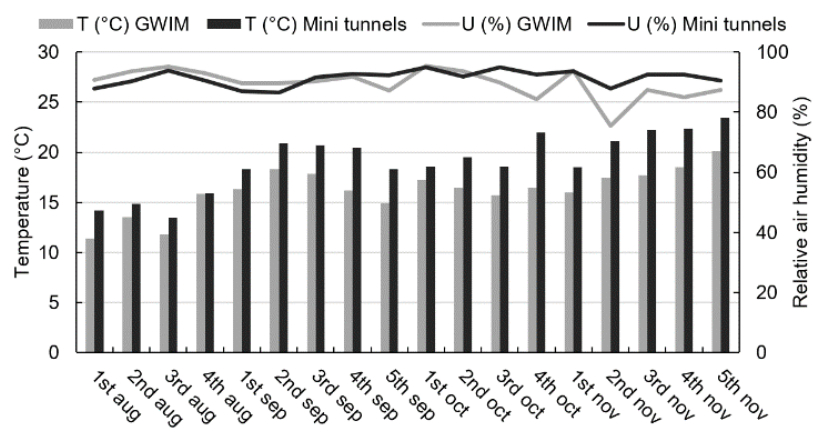

Figure 1. Weekly data of average temperature $\left({ }^{\circ} \mathrm{C}\right)$ and relative air humidity (\%) of the cutting experiment according of I. paraguariensis mother tree genotypes, for mini tunnels (Greenhouse) in Lages and greenhouse with intermittent misting (GWIN) in Otacílio Costa. 
After 130 days (November 2017) survival (\%), presence of new sprouts (\%), average number of new leaves, callus formation (\%), rooting (\%), average number of roots and, average length of the three longest roots $(\mathrm{cm})$ were evaluated.

\section{IBA use in I. paraguariensis cuttings}

Canopy sprouts from I. paraguariensis were randomly collected from ten mother trees in the study area in April 2017, under the same shading condition. We collected material from several mother trees to guarantee the genetic variability of the cuttings to be produced. The sprouts were arranged in a Styrofoam box with water to reduce transpiration and transported to the Forest Nursery of UDESC, in the municipality of Lages.

The sprouts were sectioned into cuttings, cut with pruning shears to a length of approximately $7 \mathrm{~cm}$, with at least one leaf having removed $50 \%$ of its area.

The IBA solutions were prepared in hydro-alcoholic medium $(50 \%$ ethanol) at concentrations: $0 \mathrm{mg} \mathrm{L}^{-1}, 2,500 \mathrm{mg} \mathrm{L}^{-1}, 5,000 \mathrm{mg} \mathrm{L}^{-1}, 7,500 \mathrm{mg} \mathrm{L}^{-1}, 10,000 \mathrm{mg} \mathrm{L}^{-1}$. Each cutting went through a 15-second immersion of its base, approximately $3 \mathrm{~cm}$, in the respective IBA solution.

After the immersion, the cuttings were put to root in tubes of $180 \mathrm{~cm}^{3}$ with a mix of commercial substrate (mixture of Pinus bark and peat, $\mathrm{pH}$ 5.4) and thin vermiculite in the ratio 1:1, with addition of $6 \mathrm{~g} \mathrm{~L}^{-1}$ slow release fertilizer (Osmocote ${ }^{\circledR} 15-9-12$ ). The trays, containing the tubes and cuttings, were placed into a mini tunnel, with micro sprinkler irrigation composed of four daily irrigations of five minutes each (Figure 2).

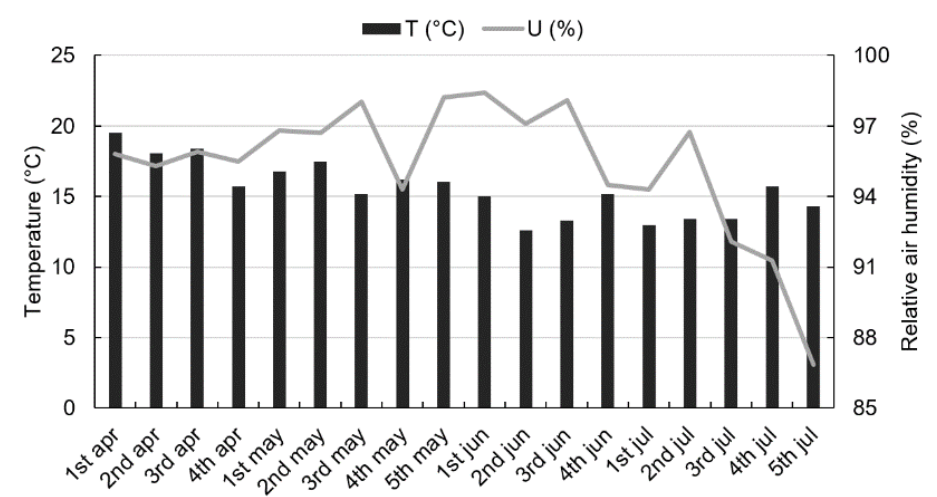

Figure 2. Weekly data of average temperature $\left({ }^{\circ} \mathrm{C}\right)$ and relative air humidity $(\%)$ of the cutting experiment of I. paraguariensis using IBA, at the UDESC forest nursery in Lages.

After 50 days, the evaluation was started, occurring every 20 days until completing 130 days (five evaluations), for the following variables: survival (\%), callus formation (\%), rooting (\%), mean number of roots and, average length of the three longest roots $(\mathrm{cm})$. The cuttings evaluated at one time were no longer used in the later evaluations to avoid interference from their manipulation.

The experiment was carried out in a completely randomized design in a $5 \times 5$ factorial scheme, with factor A consisting of five treatments of IBA doses, and factor B being the five evaluations carried out (from March to July).

\section{Statistical analysis}

We evaluated the normality of the data from both experiments, where, with significance at $5 \%$ probability by analysis of variance (Two-Way ANOVA) and with normality Scott-Knott (for the genotypes experiment) and regression (for the IBA experiment), also with a 5\% probability of error, were applied by the statistical program R software. 


\section{RESULTS AND DISCUSSION}

\section{Cutting of different genotypes of $I$. paraguariensis in two rooting environments}

There was a significant interaction between rooting environments and the I. paraguariensis mother tree genotypes for survival (\%), callus formation (\%), rooting (\%), mean number of roots and mean root length $(\mathrm{cm})$ (Table 1).

Table 1. Survival (\%), callus formation (\%), rooting (\%), mean number of roots and average length of the three largest roots $(\mathrm{cm})$ in cuttings of $I$. paraguariensis according to

\begin{tabular}{|c|c|c|c|c|c|c|c|}
\hline \multirow{2}{*}{$\begin{array}{c}\text { Rooting } \\
\text { environment }\end{array}$} & \multicolumn{6}{|c|}{ Genotype } & \multirow{2}{*}{ Averages } \\
\hline & G1 & G2 & G3 & G4 & G5 & G6 & \\
\hline \multicolumn{8}{|c|}{ Survivor (\%) } \\
\hline GWIN & $43.8 \mathrm{bB} *$ & $20.8 \mathrm{aC}$ & $25.0 \mathrm{bC}$ & $29.2 \mathrm{bC}$ & $50.0 \mathrm{bB}$ & $70.8 \mathrm{aA}$ & 39.9 \\
\hline Mini tunnels & 72.9 aA & $27.1 \mathrm{aB}$ & $68.8 \mathrm{aA}$ & $54.2 \mathrm{aB}$ & $72.9 \mathrm{aA}$ & $75.0 \mathrm{aA}$ & 61.8 \\
\hline Averages & 58.3 & 23.9 & 46.9 & 41.7 & 61.4 & 72.9 & $50.9 * *$ \\
\hline \multicolumn{8}{|c|}{ Callus formation (\%) } \\
\hline GWIN & 41.7 bB & $20.8 \mathrm{aC}$ & $20.8 \mathrm{bC}$ & 29.2 bC & 41.7 bB & $56.3 \mathrm{aA}$ & 35.1 \\
\hline Mini tunnels & $62.5 \mathrm{aA}$ & $22.9 \mathrm{aC}$ & $60.4 \mathrm{aA}$ & $54.2 \mathrm{aA}$ & $72.9 \mathrm{aA}$ & $41.7 \mathrm{aB}$ & 52.4 \\
\hline Averages & 52.1 & 21.9 & 40.6 & 41.7 & 57.3 & 48.9 & 43.8 \\
\hline \multicolumn{8}{|c|}{ Rooting (\%) } \\
\hline GWIN & $6.3 \mathrm{aB}$ & $0.0 \mathrm{aB}$ & $0.0 \mathrm{aB}$ & $2.0 \mathrm{aB}$ & $12.5 \mathrm{aB}$ & $45.8 \mathrm{aA}$ & 11.1 \\
\hline Mini tunnels & $2.0 \mathrm{aB}$ & $0.0 \mathrm{aB}$ & $2.0 \mathrm{aB}$ & $0.0 \mathrm{aB}$ & $2.0 \mathrm{bB}$ & $22.9 \mathrm{bA}$ & 4.9 \\
\hline Averages & 4.2 & 0.0 & 1.0 & 1.0 & 7.3 & 34.4 & 8.0 \\
\hline \multicolumn{8}{|c|}{ Average number of roots } \\
\hline GWIN & $>0.1 \mathrm{aB}$ & NR & NR & $>0.1 \mathrm{aB}$ & $0.3 \mathrm{aB}$ & $4.3 \mathrm{aA}$ & 0.8 \\
\hline Mini tunnels & $>0.1 \mathrm{aA}$ & NR & $>0.1 \mathrm{aA}$ & NR & $>0.1 \mathrm{aA}$ & $1.3 \mathrm{bA}$ & 0.2 \\
\hline Averages & $>0.1$ & NR & $>0.1$ & $>0.1$ & 0.2 & 2.8 & 0.5 \\
\hline \multicolumn{8}{|c|}{ Average length of the three longest roots $(\mathrm{cm})$} \\
\hline GWIN & $0.1 \mathrm{aB}$ & NR & NR & $>0.1 \mathrm{aB}$ & $0.2 \mathrm{aB}$ & $1.5 \mathrm{aA}$ & 0.3 \\
\hline Mini tunnels & $>0.1 \mathrm{aA}$ & NR & $>0.1 \mathrm{aA}$ & NR & $>0.1 \mathrm{aA}$ & $0.3 \mathrm{bA}$ & $>0.1$ \\
\hline Averages & $>0.1$ & NR & $>0.1$ & $>0.1$ & 0.1 & 0.9 & 0.2 \\
\hline
\end{tabular}

*Averages followed by the same letter do not differ among themselves by the Scott-Knott averages test $(P<0.05)$, Lowercase letters for rooting environments (column) and uppercase for genotypes (row), ** Overall average of each variable, NR: not rooted.

There was a great variation of the survival averages for the genotypes considering both rooting environments, with higher or lower level of expression. The genotype with higher survival rate was G6 (70.8\% for GWIN and $75.0 \%$ for mini tunnels) which also presented the lowest variation between rooting environments (4.2\%). In a survival contrast, $G 2$ had the lowest averages of survival in both environments (20.8\% for GWIN and $27.1 \%$ for mini tunnels). Aside from genotype G6, the genotypes G1, G3 and G5 also had a high survival rate $(72.9 \%$, $68.8 \%$ and $72.9 \%$, respectively), but only in the mini tunnel system. Some of these genotypes had differences of survival between rooting environments of more than $40.0 \%$ (G3).

Genetically superior I. paraguariensis clones can ensure a longer survival time in the rooting environment compared to clones not that well adapted (Brondani et al., 2008). Regardless of the rooting environment, genotypes G1, G5 and mainly G6 gave the highest percentages of live cuttings. The survival of propagules is directly linked to the genetics of the 
mother plant used (Franzon et al., 2010), which is possible to be improved with the better environment, in this case with the mini tunnel system.

The higher mortality of cuttings in the GWIN, for most of the genotypes, may have been caused by the lower humidity observed in the first two weeks (up to 75.5\%) of the last month of permanence in relation to the mini tunnels (constantly above $90.0 \%$ ). Humidity must be kept as high as possible around the propagules (Xavier et al., 2013). It is possible that some genotypes (such as G6 and G5) are adapted to lower humidity conditions than the recommended, with cuttings able to withstand more severe conditions. In contrast, G1, G3 and G4 are probably more sensitive to sudden humidity decreases, considering the high differences of survival between environments $(29.1 \%, 43.8 \%$ and $25.0 \%$, respectively). As for G2, the low survival rate in both environments could be due to many factors, such as genetics and the ontogenetic age of the mother tree.

Different from the survival variable, a higher variation of callus formation was obtained between both factors. G5 (72.9\%), G1 (62.5\%), G3 (60.4\%) and G4 (54.2\%) gave the highest percentages for this variable for cuttings inside the mini tunnel. Only G6 (56.3\%) achieved this statistical level inside GWIN, while G1 (41.7\%) and G5 (41.7\%) had intermediate results, and G2 (20.8\%), G3 (20.8\%) and G4 (29.2\%) the lowest. The more profuse callus formation in some genotypes, mainly in the mini tunnel system, suggests that if these cuttings remained in this environment for longer periods, there might be a greater chance of rooting (Stuepp et al., 2017b). Data from works regarding I. paraguariensis vegetative propagation suggests that there is a tendency for primary rooting, i.e., root formation without the need of previous callus presence in this species (Stuepp et al., 2015, 2017a, 2017b).

When observing both callus formation and rooting, some genotypes with high percentages of callus had low percentages or even no root formation (Table 1), for example G1 (with high percentages of cutting survival in both environments), this genotype had a medium rate of callus formation in GWIN (41.7\%) and high for mini tunnels (62.5\%), and inverse results were obtained for rooting in GWIN (6.3\%) and mini tunnels (2.0\%). It is important to observe that the genotypes that yielded low percentages of callus formation (G2, G3 and G4) also had the lowest survival percentages.

As for rooting itself, the highest rooting average was obtained in G6 (45.8\% in GWIN and $22.9 \%$ in mini tunnels) compared to the others, in which, there was no rooting or it was very low. G1 and G5 had a considerable root formation, but only in GWIN (6.3\% and 12.5\% respectively). G2 gave no rooted cuttings, while G3 and G4 had both one cutting with roots formed (inside the mini tunnels for G3 and inside GWIN for G4). Those results were examined for average number of roots formed and average length of the three longest roots, the highest results were also obtained by G6 (4.3 roots with $1.5 \mathrm{~cm}$ in GWIN, and 1.3 roots with $0.3 \mathrm{~cm}$ ). Since the other genotypes presented low or no roots, such variables as number of roots and their lengths were also very low or nonexistent (Table 1).

As for rooting and its variables, the abrupt changes in temperature between the end of the penultimate month and the beginning of the last one in the mini tunnels (approximately $3.5^{\circ} \mathrm{C}$ ) may have hampered cell differentiation due to changes in metabolism and absorption capacity of nutrients (Cunha et al., 2009). Temperatures above $15^{\circ} \mathrm{C}$ and below $35^{\circ} \mathrm{C}$ provide the best rooting of propagules by maintaining high humidity, lower transpiration and metabolism at appropriate levels (Goulart \& Xavier, 2008). This was observed for the experiment, in which there were similar averages, although mild, of temperatures between GWIN $\left(16.2^{\circ} \mathrm{C}\right)$ and the mini tunnels $\left(19.1^{\circ} \mathrm{C}\right)$. The probable environmental factor that affected the rooting of cuttings in the mini tunnels was the lower nocturnal temperatures, since in this environment this control did not occur. Still, the statistically equal results of rooting for both environments indicate that I. paraguariensis cuttings can be accommodated in simpler and cheaper structures, since the gains are similar.

The correlation between environments and genotypes can promote changes in rooting of cuttings, according to their adaptation. Environments with temperature control and irrigation by nebulization favors the survival and rooting of certain genotypes and negatively interfere with others (Brondani et al., 2008). In the present search, the G1, G3, G4 and G5 
genotypes showed greater dependence on the environment for survival, while G1, G5 and G6 were more dependent on the rooting of their cuttings. In woody species, rooting of propagules is dependent on the genotype of the host plant, which may reflect on the environment, requiring different cultivation conditions for the same species (Mokotedi et al., 2000).

Vegetative propagation is an excellent method to obtain quick genetic improvement of forest tree species, allowing the multiplication of genetically superior plants in a short period of time (Wendling et al., 2014). However, all the variables influencing rooting in a single genotype called " $\mathrm{C}$ " factor which are attributed to the unique physiological or morphological characteristics of the propagules are still unknown and can be reflected in the rooting environment (Radosta et al., 1994). The success of rooting obtained for genotype G6 may have been caused by some factor outside the genetic proper or the conditioning environment, and may be associated with the variables related to the maturation of the mother tree, the propagule used for the cutting or the environment in which the tree was.

For sprouting variables and average number of new leaves there was no significant interaction between the rooting environments and the I. paraguariensis genotypes used.

Regarding the presence of new shoots, cuttings from G6 (65.6\%), G5 (56.3\%) and G1 (53.2\%) presented at least twice as many shoots when compared to the G3 genotypes (25.0\%), and G2 (11.4\%). As for the conditioning environment, cuttings kept in the mini tunnels had a superior capacity for $(P<0.05)$ sprouting $(46.5 \%)$ than in the GWIN $(35.1 \%)$.

The new leaves were directly attached to the new sprouts, where G6 (3.4) and G1 (2.9) produced the highest average number of leaves per cutting. In contrast, G5 (1.9) was lower, but still better by six times than $\mathrm{G} 2$, which gave the lowest average (0.3). For the environments, both the mini tunnels (1.8) and the GWIN (1.7) were statistically the same for the production of new leaves $(P<0.05)$ (Figure 3 ).

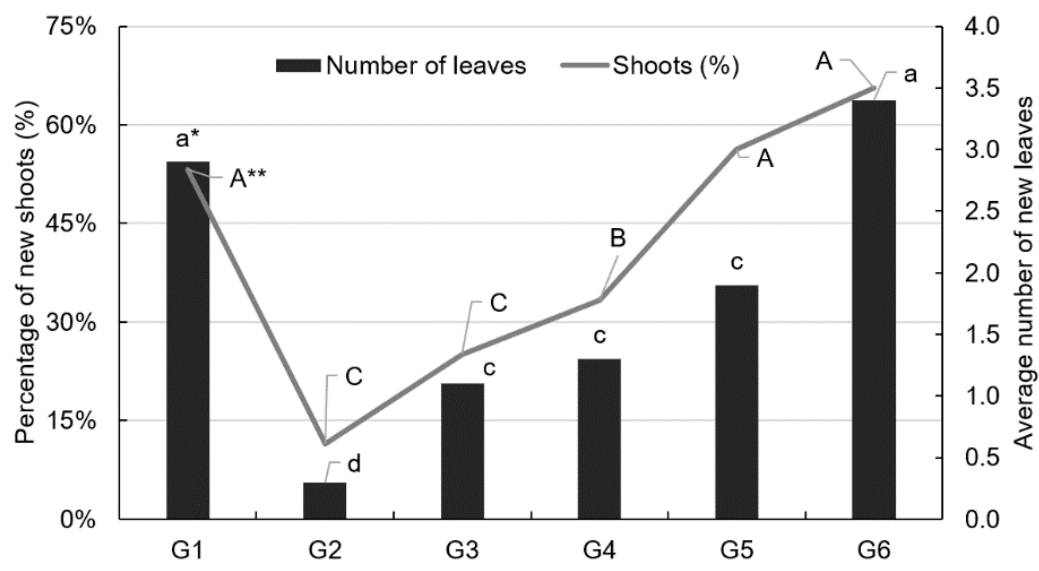

Figure 3. Averages of new sprouts (\%) and number of leaves according to the cutting of different genotypes of $I$. paraguariensis. *Averages followed by the same letter do not differ among themselves by the Scott-Knott averages test $(P<0.05)$, Lowercase letters for number of leaves and uppercase for percentage of new sprouts.

New sprouts and the numbers of new leaves appear to be dependent only on the genotype, where a favorable environment would be responsible for the increase of these variables (Brondani et al., 2008, 2009). This was verified in the present study, since there was no interaction between environmental and genotypic factors for these variables.

\section{IBA use in I. paraguariensis cuttings}

There was no significant interaction between IBA concentrations and evaluation days. Considering the days of evaluation after cutting, survival decreased continuously from the first evaluation, at 50 days (90.6\%) to 130 days (52.1\%). The highest development of callus occurred between the $70^{\text {th }}$ day $(37.5 \%)$ and the $90^{\text {th }}$ day $(50.0 \%)$ evaluation, and gradually decreased 
until the last evaluation (55.2\%). Rooting was detected in the second evaluation with one rooted cutting $(0.3 \%)$, increasing significantly between 90 days (6.3\%) and 110 days (18.8\%), which was maintained in the last evaluation (19.5\%). As a consequence of rooting, the mean number of roots and their mean length were determined from the second evaluation $(<0.1$ and $<0.1 \mathrm{~cm}$ ), increasing according to the highest rooting percentage until the final evaluation $(0.3$ and $0.6 \mathrm{~cm}$ ) (Figure 4).

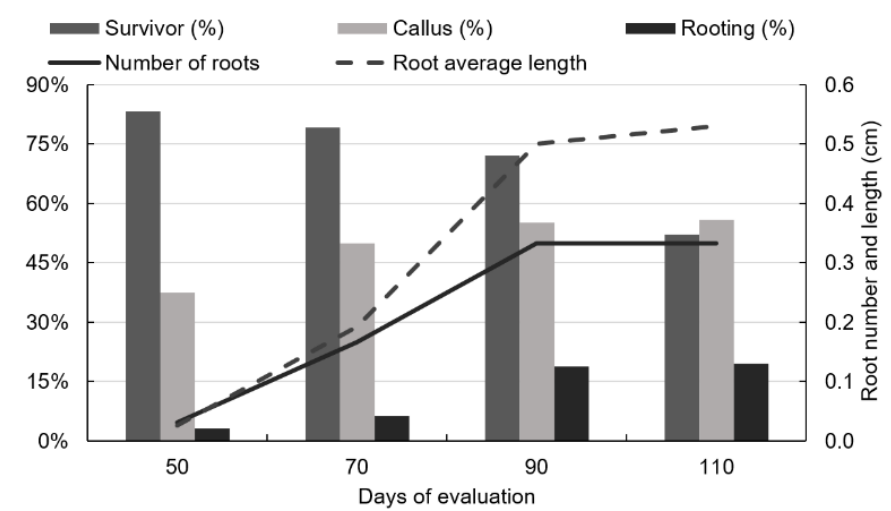

Figure 4. Survival (\%), callus formation (\%), rooting (\%), mean number of roots formed and their average length $(\mathrm{cm})$ of $I$. paraguariensis cuttings during the evaluation periods (50 to 130 days).

Regarding the evaluation periods, there was a difference of $39.0 \%$ in the survival of cuttings, considering the first evaluation (50 days) (91.0\%) and the last (130 days) (52.0\%). This relation can be considered normal, since there is the consumption of the energy reserves so that the cuttings are kept alive. At the end of the reserves, and without any efficient means of obtaining water and nutrients for the process of photosynthesis (roots) death of the cutting occurs. Survival did not change significantly related to the increase in IBA concentrations, varying at most $13.0 \%$ between no application ( $\left.0 \mathrm{mg} \mathrm{L}^{-1}\right)$ and at the maximum doses $\left(10,000 \mathrm{mg} \mathrm{L}^{-1}\right)$.

In relation to IBA concentrations, there were no significant changes in the survival of 1. paraguariensis cuttings according to its increase, with the highest percentage detected at $2,500 \mathrm{mg} \mathrm{L}^{-1}(80.8 \%)$ and the lowest at $10,000 \mathrm{mg} \mathrm{L}^{-1}(65.0 \%)$. Callus formation decreased linearly, from $0 \mathrm{mg} \mathrm{L}^{-1}(55.0 \%)$ to the maximum concentration (30.0\%) (Figure 5).

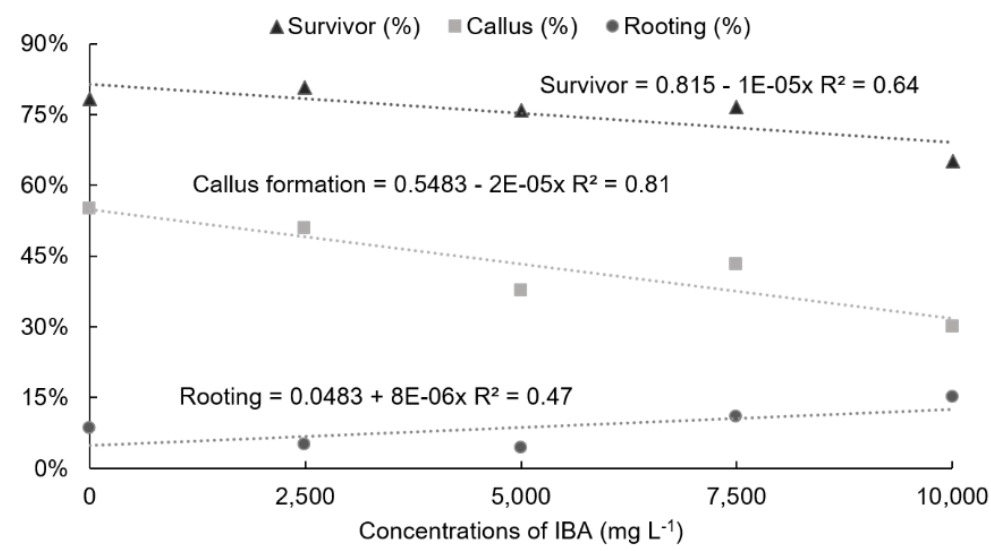

Figure 5. Survival (\%), callus formation (\%) and rooting (\%) of I. paraguariensis cuttings according to the IBA doses during the evaluation periods (50 to 130 days). Average number of roots and length of roots were not significant for regression $(P<0.05)$.

The rooting was best correlated linearly to the increase of concentration, especially at $7,500 \mathrm{mg} \mathrm{L}^{-1}(10.8 \%)$ and $10,000 \mathrm{mg} \mathrm{L}^{-1}(15.0 \%)$. On the other hand, cuttings without IBA application resulted in considerable rooting (8.3\%) compared to the highest concentrations. 
Due to the best rooting found in the concentrations of $0 \mathrm{mg} \mathrm{L}^{-1}, 7,500 \mathrm{mg} \mathrm{L}^{-1}$ and 10,000 of IBA, these concentrations gave the highest average number of roots with the highest average length. Although in similar numbers, root length at the highest concentration was $25 \%$ longer $(0.5 \mathrm{~cm})$ than $0 \mathrm{mg} \mathrm{L}^{-1} \mathrm{IBA}(0.4 \mathrm{~cm})$, while $5,000 \mathrm{mg} \mathrm{L}^{-1}$ had the shortest length $(<0.1 \mathrm{~cm})$.

The use of high concentrations of IBA can affect the survival of cuttings, presenting toxicity and its consequent death (Mantovani et al., 2017; Teixeira et al., 2017), but this was not detected in the present search. The higher survival of cuttings may be related to the time of collection of propagules, in which cold periods, such as autumn and winter, provide the greatest survival of cuttings of I. paraguariensis, regardless of IBA concentrations (Stuepp et al., 2017a). This is because the shoots collected in these periods have a good accumulation of reserves, providing more energy for the cuttings to grow, and consequently, extending their survival time (Oliveira et al., 2012).

According to the evaluation periods, there was a considerable amount of callus in cuttings of I. paraguariensis (18.0\%), which could indicate a high maturation of the plant material used (Wendling et al., 2014; Stuepp et al., 2015). Considering the IBA concentrations, there was a strong decrease in callus formation according to IBA increase (up to $25.0 \%$ less) and consequently there was also an increase in rooting. The presence of callus in cuttings of 1. paraguariensis hampers its rooting, indicating that the formation of roots for the species is best carried out directly (Stuepp et al., 2017a). This may indicate that, besides originating from a material with high maturation, the cuttings of this search did not have endogenous auxins at sufficient levels for efficient cell differentiation, necessitating an exogenous source (Wendling et al., 2015), which in this case were the highest concentrations $\left(7,500 \mathrm{mg} \mathrm{L}^{-1}\right.$ and $\left.10,000 \mathrm{mg} \mathrm{L}^{-1}\right)$. However, plant materials, which in the presence of growth regulators produce little or no rooting, may have some inhibitory substance or deficiency of some compound necessary for that process (Hartmann et al., 2011).

The efficiency of IBA in the rooting of $I$. paraguariensis cuttings may be linked to the time of application in the experiment. With propagules collected in the winter and coming from aged mother trees, rooting tends to increase according to the increase of IBA concentrations, although it still occurs in low percentages (Stuepp et al., 2017a). This happened in the present study and rooting did not exceed $15.0 \%$ in the concentration of $10,000 \mathrm{mg} \mathrm{L}^{-1}$, which would reinforce the hypothesis that the shoots used for the cutting were from mature mother trees (Ferreira et al., 2010; Wendling et al., 2014) and that only with high exogenous doses (Wendling et al., 2015) there is success in rooting. However, the shoots collected for this experiment come from plants with an average age of 15 years, considered to be young. Thus we can attribute another factor for their lower vegetative development, such as the environment. The city of Urupema is nationally known as being the coldest of Brazil, having a well adapted vegetation. It is possible that I. paraguariensis mother trees have a slower vegetative development under this condition, presenting a lower vegetative propagation capability.

As a consequence of the rooting, the average number of roots and the average length of the three longest roots were higher according to the periods of evaluation and the increase of IBA concentrations. Cuttings treated with growth regulators can start the rooting process before the untreated ones, which explains the greater number and length of roots (Stuepp et al., 2015), since the evaluations of the treatments were done at the same time.

\section{CONCLUSIONS}

Survival and rooting success of I. paraguariensis cuttings are directly linked to the conditioning environment and to the genetic characteristics of the mother trees which favors these variables,

Environments with micro sprinkler irrigation maintain a greater number of cuttings alive, while by nebulization they guarantee better rooting,

Although difficult due to selection criteria, the use of superior mother trees genotypes for cutting is essential for the success of its rooting in this species, 
There were no significant results regarding the use of IBA in the rooting of cuttings in this study, even when considering the highest doses,

Further studies on the selection of I. paraguariensis mother trees are required for its vegetative propagation, determining selection criteria.

\section{BIBLIOGRAPHY}

Brondani, G. E., Araújo, M. A., Wendling, I., \& Kratz, D. (2008). Enraizamento de miniestacas de ervamate sob diferentes ambientes. Pesquisa Florestal Brasileira, (57), 29-38.

Brondani, G. E., Wendling, I., Araújo, M. A., Santin, D., Benedetti, E. L., \& Roveda, L. F. (2009). Composições de substratos e ambiente de enraizamento na estaquia de llex paraguariensis A. St.Hil. Revista Floresta, 39(1), 41-49. http://dx.doi.org/10.5380/rf.v39i1.13724.

Cunha, A. C. M. C. M., Paiva, H. N., Leite, H. G., Barros, N. F., \& Leite, F. P. (2009). Influência do estado nutricional de minicepas no enraizamento de miniestacas de eucalipto. Revista Árvore, 33(4), 607615. http://dx.doi.org/10.1590/S0100-67622009000400003.

Dartora, N., Souza, L. M., Paiva, S. M., Scoparo, C. T., lacomini, M., Gorin, P. A., Rattmann, Y. D., \& Sassaki, G. L. (2013). Rhamnogalacturonan from llex paraguariensis: A potential adjuvant in sepsis treatment. Carbohydrate Polymers, 92(2), 1776-1782. PMid:23399219. http://dx.doi.org/10.1016/j.carbpol.2012.11.013.

Dias, P. C., Oliveira, L. S., Xavier, A., \& Wendling, I. (2012). Estaquia e miniestaquia de espécies florestais lenhosas do Brasil. Pesquisa Florestal Brasileira, 32(72), 453-462. http://dx.doi.org/10.4336/2012.pfb.32.72.453.

Ferreira, B. G. A., Zuffellato-Ribas, K. C., Wendling, I., Koehler, H. S., \& Nogueira, A. C. (2010). Miniestaquia de Sapium glandulatum (Vell.) Pax com o uso de ácido indol butírico e ácido naftaleno acético. Ciência Florestal, 20(1), 19-31. http://dx.doi.org/10.5902/198050981758.

Franzon, R. C., Gonçalves, R. S., Antunes, L. E. C., \& Raseira, M. C. B. (2010). Propagação vegetativa de genótipos de pitangueira do sul do Brasil por enxertia de garfagem. Revista Brasileira de Fruticultura, 32(1), 262-267. http://dx.doi.org/10.1590/S0100-29452010005000003.

Goulart, P. B., \& Xavier, A. (2008). Efeito do tempo de armazenamento de miniestacas no enraizamento de clones de Eucalyptus grandis x E. urophylla. Revista Árvore, 32(4), 671-677. http://dx.doi.org/10.1590/S0100-67622008000400008.

Hartmann, H. T., Kester, D. E., Davies Junior, F. T., \& Geneve, R. L. (2011). Hartmann and Kester's plant propagation: principles and practices (8th ed., 915 p.). Boston: Prentice-Hall.

Mantovani, N., Roveda, M., Tres, L., Fortes, F. O., \& Grando, M. F. (2017). Cultivo de canafístula (Peltophorum dubium) em minijardim clonal e propagação por miniestacas. Ciência Florestal, 27(1), 225-236. http://dx.doi.org/10.5902/1980509826461.

Mokotedi, M. E. O., Watt, M. P., Pammenter, N. W., \& Blakeway, F. C. (2000). In vitro rooting and subsequent survival of two clones of cold-tolerant Eucalyptus grandis $\times$ Eucalyptus nitens Hybrid. HortScience, 35(6), 1163-1165. http://dx.doi.org/10.21273/HORTSCI.35.6.1163.

Oliveira, R. J. P., Bianchi, V. J., Aires, R. F., \& Campos, A. D. (2012). Teores de carboidratos em estacas lenhosas de mirtileiro. Revista Brasileira de Fruticultura, 34(1), 199-207. http://dx.doi.org/10.1590/S0100-29452012000400029.

Pires, P. P., Wendling, I., \& Brondani, G. E. (2013). Ácido indolbutírico e ortotropismo na miniestaquia e de Araucaria angustifolia. Revista Árvore, 37(3), 393-399. http://dx.doi.org/10.1590/S010067622013000300002.

Radosta, P., Paques, L. E., \& Verger, M. (1994). Estimation of genetic and non-genetic parameters for rooting traits in hybrid larch. Silvae Genetica, 43, 108-114.

Stuepp, C. A., Bitencourt, J., Wendling, I., Koehler, H. S., \& Zuffellato-Ribas, K. C. (2017a). Age of stock plants, seasons and iba effect on vegetative propagation of llex paraguariensis. Revista Árvore, 41(2), 1-7.

Stuepp, C. A., Bitencourt, J., Wendling, I., Koehler, H. S., \& Zuffellato-Ribas, K. C. (2017b). Métodos de resgate e idade cronológicas de plantas-matrizes no enraizamento de brotações epicórmicas de Ilex paraguariensis. Ciência Florestal, 27(4), 1409-1413. http://dx.doi.org/10.5902/1980509830223.

Stuepp, C. A., Bitencourt, J., Wendling, I., Koehler, H. S., \& Zuffellato-Ribas, K. C. (2015). Propagação de erva-mate utilizando brotações de anelamento e decepa em matrizes de duas idades. Cerne, 21(4), 519-526. http://dx.doi.org/10.1590/01047760201521041864. 
Teixeira, M., Filter, M., Périco, E., Freitas, E. M., \& Sperotto, R. A. (2017). Efficiency of indolebutyric acid and different substrates in yerba mate cuttings. Iheringia. Série Botânica, 72(3), 388-393. http://dx.doi.org/10.21826/2446-8231201772308.

Wendling, I., \& Brondani, G. E. (2015). Produção de mudas de erva-mate. In I. Wendling \& D. Santin (Eds.), Propagação e nutrição de erva-mate (21. ed., 195 p.). Colombo: EMBRAPA.

Wendling, I., \& Dutra, L. F. (2010). Produção de mudas de eucalipto. Colombo: Embrapa Florestas. 184 p.

Wendling, I., Trueman, S. J., \& Xavier, A. (2014). Maturation and related aspects in clonal forestry-part II: reinvigoration, revitalization and juvenility maintenance. New Forests, 1(4), 1-14. http://dx.doi.org/10.1007/s11056-014-9415-y.

Wendling, I., Warburton, P. M., \& Trueman, S. J. (2015). Maturation in Corymbia torelliana $\times$ C. citriodora stock plants: effects of pruning height on sprout production, adventitious rooting capacity, stem anatomy, and auxin and abscisic acid concentrations. Forests, 6(12), 3763-3778. http://dx.doi.org/10.3390/f6103763.

Xavier, A., Wendling, I., \& Silva, R. L. (2013). Silvicultura clonal: princípios e técnicas (2. ed., 279 p.). Viçosa: UFV.

Author's contributions: BN: Conceptualization, data curation, formal analysis, investigation, methodology, visualization, writing - original draft, writing - review and editing, ACSS: Data curation, investigation, CM: Data curation, investigation, JCPS: Resources, MOP: Conceptualization, methodology, supervision, visualization, MCN: Conceptualization, data curation, formal analysis, funding acquisition, investigation, methodology, project administration, supervision, validation. 